\title{
A review of cardiac involvement in COVID-19 infection
}

\author{
Zeinab Mohseni Afshara, Arefeh Babazadeh ${ }^{b}$, Mostafa Javanian $^{b}$, \\ Elham Ramezanic, Reyhaneh Shemshadid, Soheil Ebrahimpourb
}

a Clinical Research Development Center, Imam Reza Hospital, Kermanshah University of Medical Sciences, Kermanshah, Iran

${ }^{b}$ Infectious Diseases and Tropical Medicine Research Center, Health Research Institute, Babol University of Medical Sciences, Babol, I.R., Iran

' Department of Cardiology, Kermanshah University of Medical Sciences, Kermanshah, Iran

${ }^{d}$ Kermanshah University of Medical Sciences, Kermanshah, Iran

\section{ARTICLE INFO}

Article history:

Submitted: 7. 7. 2020

Accepted: 18. 7. 2020

Available online: 1. 12. 2020

\section{Klíčová slova:}

COVID-19

Opatření

Péče o pacienty s onemocněním

srdce

Postižení srdce

\section{SOUHRN}

Nové onemocnění pod označením COVID-19 (coronavirus disease 2019), tedy těžký akutní respirační syndrom vyvolaný koronavirem 2 (severe acute respiratory syndrome coronavirus 2, SARS-CoV-2), v současnosti představuje naléhavý problém veřejného zdraví v celosvětovém kontextu (public health emergency of international concern, PHEIC). Podle některých studií může SARS-CoV-2 vést ke kardiovaskulárním komplikacím, jako jsou myokarditida, poškození myokardu, akutní infarkt myokardu, arytmie, srdeční selhání a kardiomyopatie. Bylo prokázáno, že diagnóza COVID-19 stanovená u pacientů s již př́tomnými komorbiditami, např. onemocněním srdce, je spojena s vyšším rizikem úmrtí. Při vyšetřování a léčbě pacientů s onemocněním COVID-19 musí mít proto lékaři tyto možné kardiovaskulární komplikace na paměti; ty ve spojení s onemocněním COVID-19 jsou také hlavním tématem tohoto přehledu.

(c) 2020, ČKS.

\section{ABSTRACT}

The novel coronavirus disease 2019 (COVID-19), caused by severe acute respiratory syndrome coronavirus 2 (SARS-CoV-2), is a public health emergency of international concern (PHEIC). Some studies reported SARS-CoV-2 may result in cardiovascular complications such as myocarditis, myocardial injury, acute myocardial infarction, arrhythmia, heart failure, and cardiomyopathy. It has been shown that COVID-19 patients with pre-existing medical conditions, such as heart disease, are at higher risk of increased mortality. Physicians should be well aware of cardiovascular complications when examining and treating patients with COVID-19 infection. Therefore, the current review assesses cardiovascular complications in COVID-19.
Keywords:

Cardiac care

Cardiac involvement

COVID-19

Precaution the latest studies relevant to the important issues to help medical doctors in their efforts to update their knowledge about COVID-19 pandemic. Many COVID-19 patients have cardiovascular disease (CVD) or develop further heart injury during the infection course.

It is well believed that the underlying heart condition is one of the main underlying causes of severe forms of COVID-19. ${ }^{3}$ The risk of heart muscle injury is higher in those with underlying heart disease, which may result in the intensive care unit (ICU) admissions and increased mortality among older persons. It is supposed that most of the patients die from heart disease rather than pneumonia. The risk of severe COVID-19 symptoms would not be similar in all cardiac patients. For example, COVID-19 may impose more cardiovascular (CV) stress in the following conditions: ${ }^{4}$ 1) immunosuppressed individuals, such as 
transplant patients, or cancer patients undergoing chemotherapy or radiotherapy; 2 ) older patients and pregnant women with underlying cardiovascular disease, and; 3) patients with heart failure, dilated or obstructive forms of hypertrophic cardiomyopathy or congenital cyanotic heart disease.

The virus does not seem to infect implanted cardiac devices such as pacemakers and implantable cardioverterdefibrillator (ICD) or induce viremia leading to infective endocarditis in individuals with valvular heart disease. ${ }^{5}$

On the other hand, COVID-19 can be imposed on preexisting cardiovascular disease (both congenital or acquired), which may cause further complications. Cardiac damage is much more likely in patients with previous heart disease. ${ }^{6}$ The mortality rate due to cardiac involvement during COVID-19 infection in previously healthy patients is less than others with a history of heart disease.

We should have a high clinical suspicion for performing initial tests, imaging, confirmative molecular tests, and also considering proper isolation in patients with either congenital or acquired heart disease to earlier diagnosis of COVID-19.

It has been observed that many deaths occurred in COVID-19 patients, without any signs and symptoms of respiratory distress. ${ }^{7}$ Therefore, it was inferred that the heart muscle infection may cause mortality; however, it is not known that myocardial damage during hospitalization poses greater risk and worse outcome.

The cases of COVID-19 related cardiomyopathy have been observed abundantly, particularly during pregnancy; therefore, an echocardiogram is strongly suggested in pregnant COVID-19 patients, especially those with critically severe disease. ${ }^{8}$

There are much evidence and reports of heart engagement during COVID-19 infection. COVID-19 induces cardiovascular complications particularly in severe symptomatic patients which may be due to the high inflammatory response during this illness.

Cardiac complications could be manifested with various features. The first and foremost one is an acute cardiac injury $(\mathrm{ACl})$ which is usually defined as the elevation of cardiac enzymes such as cardiac troponin I (cTnl) and/or electrocardiographic changes along with the clinical findings of cardiac decompensation. ${ }^{9}$ This condition may result from direct cardiomyocyte injury through binding of SARS-CoV-2 to angiotensin-converting enzyme 2 (ACE2), systemic inflammation (manifested with proinflammatory cytokines increase and due to cytokine release storm which is the result of acute systemic inflammatory response) or secondary hemophagocytic lymphohistiocytosis or stress cardiomyopathy, myocardial oxygen demand supply imbalance, acute coronary event, or iatrogenic events. Any of these conditions would adversely affect the prognosis.

Other manifestations of cardiac involvement are as follows: ${ }^{2,3}$ acute coronary event resulted from inflammation-induced plaque rupture or worsening of underlying coronary artery disease (CAD) which sometimes leads to prothrombotic states; left ventricular systolic dysfunction which may lead to heart failure or cardiogenic shock; arrhythmia including both tachyarrhythmias and brady- arrhythmias; adverse cardiac influences of some medications used for COVID-19 therapy; electrolyte abnormalities such as hypokalemia is associated with the risk of arrhythmias; and potential long-term adverse effects on lipid profile, glucose metabolism, and cardiovascular homeostasis. In brief, the inflammatory cytokine release after infection might lead to coronary blood flow decrease, oxygen supply reduction, coronary plaque instability, and increased thrombogenesis susceptibility.

Myocarditis is the main concern in COVID-19 related cardiac effects. ${ }^{10}$ The method of choice for diagnosis of myocarditis is cardiac magnetic resonance imaging (MRI) or endomyocardial biopsy (EMB), which are not performed routinely; thus the diagnosis is based on cardiac enzymes elevation in conjunction with echocardiographic evidence of acute myocarditis (such as segmental wall motion abnormalities, decreased left ventricular ejection fraction or left ventricular wall thickening or pericardial effusion) and electrocardiogram (ECG) changes (ST elevation or ST/T segment changes). COVID-19 is believed to cause myocardial injury somehow manifested by elevation of troponin and heart failure. ${ }^{11}$

Furthermore, fulminant myocarditis with cardiogenic shock has also been observed. Some studies have been suggested that anti-oxidative therapy such as vitamin C, vitamin $\mathrm{E}$ may reduce the severity or avoid cardiac injuries of severe COVID-19 infection by combatting against the virus-induced profound immunological reactions, cytokine storm and immune-cell infiltration. ${ }^{12,13}$ Another potential condition caused by COVID-19 pneumonia is venous and pulmonary thromboembolism, which may present with dyspnea and sometimes hemoptysis. The underlying reason for this potentially lethal consequence can be the hypercoagulable state that is imposed by COVID-19; therefore, close monitoring of these patients and the performance of preventive measures would be vital.

An important complication commonly observed in the course of COVID-19 is the endothelial damage caused by inflammation, which induces a procoagulant state leading to venous or pulmonary thrombosis and cerebrovascular disease. To avoid this critical situation, effective anticoagulant preventive measures should be considered based on D-dimer levels. ${ }^{14}$ In this condition, respiratory decompensation with other clinical signs and symptoms of venous thromboembolism should raise suspicion for pulmonary embolism. Moreover, COVID-19 may mimic pulmonary thromboembolism and it should be in the differential diagnoses of this condition. Also, elevated Ddimer levels $(>1 \mu \mathrm{g} / \mathrm{mL})$ and fibrin degradation products (FDP) levels are strongly associated with in-hospital mortality, because of the probability of disseminated intravascular coagulation (DIC). ${ }^{15,16}$

It is beneficial to stratify adult patients with complex congenital heart disease for the risk of developing COVID-19 complications based on their function class. In other word, the more complicated viral infections might develop due to the higher stage of their cardiac symptoms. Heart failure in the setting of COVID-19 is most commonly the result of an exacerbation of pre-existing left ventricular dysfunction. ${ }^{6}$ However, sometimes, cardiomyopathy or pulmonary hypertension in the context of critical paren- 
chymal lung involvement and acute respiratory distress syndrome (ARDS) may be responsible for this issue.

Because of different approaches and management, it is important to differentiate cardiogenic and mixed shock from septic shock and ARDS in the setting of COVID-19. The clues to distinguish these two conditions are serum brain natriuretic peptide (BNP) measurement and echocardiography. ${ }^{17}$

Myocardial injury detected by elevation of troponin T (TnT) levels, is the main cause of mortality in COVID-19 patients. ${ }^{11}$ In addition to TnT levels elevation, which is the result of troponin leak due to cytokine storm and myocardial dysfunction, brain natriuretic peptide (BNP) is also elevated in this condition. In one study, N-terminal (NT)pro hormone BNP (NT-proBNP) levels of greater than 900 $\mathrm{pg} / \mathrm{mL}$ were reported to be an independent risk factor of mortality. ${ }^{18,19}$ ST-segment changes on an electrocardiogram, symptoms of the acute coronary syndrome such as chest pain, arrhythmias, or evidence of heart failure, thorough evaluation might be necessary for myocardial involvement.

It should be noted that the detection of abnormal troponins in a critically ill COVID-19 patient does not affect the management of the patient. However, control of blood pressure, heart failure handling with medications, secondary infection treatment, maintaining renal function, and support of respiratory function even with ventilators, are mainstays of cardiac involvement management.

\section{Electrocardiographic manifestations of COVID-19 patients}

Heart rhythm problems (heart arrhythmias) are one of the common cardiovascular manifestations in COVID-19 patients. The heart palpitations are the most prevalent and nonspecific of them which observed as a presenting symptom some admitted patients. ${ }^{20}$ Acute cardiac injury, which is a common feature of the severe stages of COVID-19 infection is reported in up to $12 \%$ of cases. ${ }^{9,21}$ It can manifest as arrhythmias and ECG changes. The causative mechanisms of these abnormalities may be the metabolic imbalance or hypoxia to neurohormonal or inflammatory stress imposed by the virus. Furthermore, ACE2-related signaling pathways are also involved in cardiac injury. Temporary S1Q3T3 pattern and subsequent reversible nearly complete atrioventricular block (AV block) may be due to local myocarditis or transient pulmonary artery hypertension imposed by a tracheal obstruction, which may lead to extensive small pulmonary artery compression. ${ }^{22}$

In these cases, pulmonary thromboembolism must be ruled out. ST segment elevation and multifocal ventricular tachycardia are caused by severe hypoxia and hypotension induced by critically ill patients with COVID-19. ${ }^{23}$

Clinicians should be aware of the underlying myocarditis in cases with new onset of significant tachyarrhythmias. It is important to know that patients with arrhythmias may be susceptible to arrhythmogenic effects of COVID-19-induced conditions such as fever, electrolyte imbalance and antivirals, relative to their inherited defect (for example long QT syndrome [LQTS], Brugada syndrome $[\mathrm{BrS}]$, short QT syndrome and catecholaminergic polymorphic ventricular tachycardia [CPVT]). ${ }^{24}$ They may be at especially increased risk of deadly arrhythmias if they become feverish. Therefore, such patients must be urgently treated with antipyretics. Interestingly, there have even been reports of $\mathrm{BrS}$ that have been unmasked by COVID-19 infection. ${ }^{25}$

\section{Association between COVID-19 treatment and cardiac medications}

Some cardiac medications potentially affect in controlling coronaviruses with various mechanisms.

\section{Chloroquine}

Chloroquine is an antimalarial agent that is used as an anti-arrhythmic drug. Chloroquine inhibits SARS-CoV- 2 by increasing endosomal $\mathrm{pH}$, which creates an inappropriate environment for coronavirus replication and also blocks virus receptor binding by altering the terminal glycosylation of ACE-2. ${ }^{26}$ Chloroquine-related cardiotoxicity manifests clinically as restrictive or dilated cardiomyopathy or conduction abnormalities. Chloroquine and hydroxychloroquine, which is a safer derivative of chloroquine, block Kv11.1 protein, which is the alpha subunit of a potassium ion channel. ${ }^{27}$ Therefore, they can cause drug-induced long QT intervals, syncope..$^{28}$ However, this arrhythmogenic effect is most probable with long-term use of other arrhythmogenic medications like azithromycin, or in the setting of metabolic imbalance (e.g. hypokalemia or hypomagnesemia), renal insufficiency, congenital LQT patients, or overdose.

Also, chloroquine can increase the concentration of some beta-blockers such as metoprolol, carvedilol (Coreg), propranolol, or labetalol, hence shifting heart rate and blood pressure..$^{29}$ In these circumstances, holding class III antiarrhythmic drugs, close monitoring of electrolytes, and watchful monitoring of ECG would be reasonable. Otherwise, cardiac monitoring would have been even unnecessary.

\section{ACE inhibitors (ACEIs) / Angiotensin II receptor blockers (ARBs)}

ACEIs/ARBs are a subset of medications that administration in the setting of COVID-19 has been discussed extensively and are still controversial. Currently, in patients already on medications such as ACEI/ARB, decisions should be made carefully for continuing or stopping the current therapy; however, it is strongly recommended to continue these drugs during COVID-19 infection. ${ }^{30}$ On the other hand, diabetic and hypertensive patients treated with ACE2-stimulating drugs such as thiazolidinediones and ibuprofen can increase the severity and mortality of COVID-19. ${ }^{31,32}$ Besides, nicotine inhalers or cigarette smokers are at higher risk of systolic and diastolic blood pressure elevation, and plasma ACE activity increase and result in a poorer outcome.

\section{Anti-retroviral drugs}

Anti-retroviral medications used to treat COVID-19 may interact significantly with cardiac drugs, hence it is necessary to consider appropriate dose modifications. For 
example, lopinavir/ritonavir may lead to QT and PR interval prolongation, especially in the cases with baseline abnormality (long QT) or those taking other QT prolonging drugs. ${ }^{33}$ Both ribavirin and lopinavir/ritonavir may influence on anticoagulant dosage. For example, ribavirin can increase or decrease warfarin levels or/and lopinavir/ritonavir may increase the levels of some drugs such as rivaroxaban, apixaban, or/and ticagrelor may decrease the levels of clopidogrel and prasugrel; therefore, precautions should be taken in the concomitant use of these medications to avoid bleeding or thrombosis. ${ }^{34,35}$

\section{HMG-CoA reductase inhibitors (statins)}

Statins have been proven to be involved in the immunomodulatory during the treatment of various autoimmune and infectious diseases. In COVID-19 outbreak, this class of medication is beneficial for the limitation of infection progression. Myopathy or rhabdomyolysis may induce due to the interaction of these drugs with lopinavir/ritonavir. ${ }^{36}$ In other words, some members of this class including lovastatin and simvastatin are contraindicated in combination with lopinavir/ritonavir, while other statins, such as atorvastatin and rosuvastatin should be adjusted.

\section{Corticosteroids}

Corticosteroids like methylprednisolone are controversiaIly used to treat critical cases of COVID-19; however, they cause fluid retention, electrolyte imbalance, and hypertension as well as interacting with warfarin. The role of steroids in COVID-19 management is very limited. ${ }^{37,38}$ Evidence suggest of steroids not only have no effect on mortality but also delay the clearance of the virus. However, fulminant myocarditis is one of the conditions that would benefit from corticosteroids.

\section{COVID-19 and cardiovascular interventions}

The COVID-19 crisis has been imposed great impacts on healthcare settings such as cardiac care. The high-risk procedures for airborne transmission include high flow oxygen, nebulization, bronchoscopy, open tracheal suctioning, intubation, extubation, and non-invasive positive pressure ventilation. Moreover, it might be necessary to perform some cardiac procedures such as transesophageal echocardiography (TEE), electrophysiological (EP) study, angiography, or cardiopulmonary resuscitation which could be a threaten for healthcare workers. ${ }^{39}$ It should be emphasized to avoid unnecessary diagnostic tests such as requesting cardiac enzymes or echocardiography in these patients to minimize the working load imposed on healthcare workers. Sterilization of catheterization labs, EP labs, and operating rooms should also be rigidly performed. To limit potential exposure to suspected or confirmed COVID-19 infected patients, cardiac procedures should be categorized into semi-urgent, urgent, or emergent ones, depending on the severity of the patient's cardiac condition and its threat for life for outpatients. ${ }^{40}$

\section{Urgent, or emergent procedures}

Urgent procedures are vital for decreasing the risk of cardiac related morbidity or mortality. In these conditions, active screening and maintaining a high level of suspicion for COVID-19 infection is critical. Examples are as follows: ${ }^{40}$ catheter ablation of hemodynamically compromising conditions such as ventricular tachycardia (VT) or supraventricular tachycardia (SVT) / atrial fibrillation (AF) I atrial flutter not responding to drugs or cardioversion; revision of malfunctioning pacemaker leads or changing generators critical for patient's survival; cardiac resynchronization therapy (CRT) in severe refractory heart failure as indicated according to guidelines; and TEE for urgent cardioversion.

\section{Semi-urgent procedures}

Semi-urgent procedures are not vital at present time but must be performed in a better condition. These procedures should also be done with appropriate personal protective equipment (PPE). Some examples are as follows: ${ }^{41}$ VT or SVT ablation in medically refractory patients and nonurgent cardiovascular implantable electronic device (CIED) generator replacement.

\section{Elective procedures}

Elective procedures are not included in the above criteria. These procedures can be postponed for several weeks or months later. Examples include: ${ }^{40}$ premature ventricular complex (PVC), SVT, AF or atrial flutter ablation in stable patients, and CRT in stable individuals or CIED upgrading.

\section{Electrophysiology (EP)}

Electrophysiologists have an important role in community health due to arrhythmias as a great cause of cardiac visits. A significant percent of COVID-19 patients have been reported to have arrhythmias. Furthermore, some patients experience cardiac arrest or asystole during active or the convalescent phase of COVID-19.42 On the other hand, during visiting clinics or hospitals for individuals without COVID-19 cardiac problems, increase the risk of acquiring or transmitting the infection through droplet or airborne producing procedures which might be a great problem in this epidemic especially for higher risk patients such as the elderly, pregnant, and immunosuppressed cases.

Such exposure puts EP personnel and physicians at increased risk of exposure to COVID-19. ${ }^{43}$ Therefore, contact between healthcare workers and COVID-19 patients should be decreased to limit this infection spread. One way to accomplish this purpose is by utilizing PPE. If possible, EP consults must be done without face-toface contact and telehealth visits should be conducted. Non-urgent or non-emergent procedures should be delayed. But, if unavoidable to visit suspected or confirmed COVID-19 infected patients, limiting the duration of the visits and the number of personnel involved should be considered. All electrophysiologists should have a high degree of suspicion for COVID-19 in any patient they contract in the inpatient or outpatient setting. Every patient should be questioned about any symptoms such as fever, cough, and shortness of breath suggestive of COVID-19, or travel history and contact with sick people. In suspected COVID-19 infected patients PPE consisting of 
a face mask, eye shield, gown, and gloves should be taken by all associated health care workers and an infectionist's consultation must be done. ${ }^{44}$ The ventilation system and disinfection protocols of EP labs should be optimized to minimize nosocomial infections.

\section{Cardiopulmonary resuscitation (CPR)}

Inevitably conditions such as cardiopulmonary arrest might happen while CPR would be necessary for COVID-19 patients. ${ }^{45}$ CPR should be performed with the least number of participants involved in the room of a cardiac arrest patient confirmed or suspected case of COVID-19, with the assurance that all involved personnels have put on proper PPE and consider airborne precautions. If possible, using video laryngoscopes is recommended to reduce the exposure time during tracheal intubation. Healthcare professionals are recommended to provide bag-valve-mask ventilation (BMV).

\section{COVID-19 and myocardial infarction (MI)}

Another important issue is the impact of COVID-19 on $\mathrm{MI}$ management. ${ }^{46}$ Due to the global fear and reluctance to healthcare settings, hospital or outpatient visits have been significantly reduced since the beginning of the epidemic. Consequently, there occur large delays in the diagnosis and management of many diseases or conditions such as MI. Delays in any intervention necessary for this cardiac condition would affect the prognosis. ${ }^{47}$ Also, even if reaching in time for intervention, the environment of catheterization laboratories can predispose to further contamination of the surrounding area, due to the positive pressure ventilation. Therefore, special precautions should be taken to avoid transmission. For cases in which COVID-19 patients develop ST-segment elevation MI, the risk-benefit ratio of primary percutaneous intervention vs fibrinolysis should be reconsidered.

\section{Precautions}

Although COVID-19 vaccine has not already been available, vaccination against influenza could prevent superinfections on COVID-19, which would worsen the situation. ${ }^{48}$ Recommendations that seem to be efficient for individuals with the underlying cardiovascular disease include: performing strict hand hygiene and other reasonable precautions especially correct face mask wearing, staying indoors and self-quarantine, keeping on exercise, balancing their diet and having healthy eating, avoiding alcohol or illicit drugs, cleaning up their sleep hygiene, avoiding close contacts especially with sick people, regular taking of their cardiac medications, updating their vaccines, and immediate medical consult in case of associated symptoms occurrence. ${ }^{49-51}$

\section{COVID-19 and heart transplant (HT)}

It is noteworthy that COVID-19 poses a significant challenge in heart transplantation, donor selection, immu- nosuppression, and post-transplant management. Studies show that the risk of COVID-19 infection in heart transplant recipients is not higher than the general population if proper precautions are taken. ${ }^{52}$ Since few studies have been done in this population, the differences in symptoms, laboratory tests, and radiographic features have not been determined. ${ }^{53}$ Also, solid organ transplantation (SOT) recipients such as heart transplant recipients are at greater risk of COVID-19 because of their potential anti- rejection immunosuppressive regimens. It is generally recommended to continue heart transplantation without changes in dose and type of immunosuppression in recipients who have not been infected with COVID-19 or have not been exposed to this infection in the last two to four weeks. ${ }^{54}$ For donors, it is necessary to rule out having a current COVID-19 infection. ${ }^{55,56}$

\section{Conclusions}

COVID-19 may cause serious cardiovascular complications comprising myocarditis, myocardial injury, Ml, arrhythmia, heart failure, and cardiomyopathy. Reports are circulating that some COVID-19 medications may increase the risk of cardiac complications. Physicians need to increase awareness of these complications while treating COVID-19 cases.

\section{Acknowledgements}

All of the authors wish to thank Department of Infectious Diseases, Babol University of Medical Ssciences, Iran.

Conflicts of interest

All authors declare no conflict of interest.

Funding body

None.

\section{Ethical statement}

The authors state that the research was conducted according to ethical standards.

\section{References}

1. Javanian M, Bayani M, Shokri M, et al. Clinical and laboratory findings from patients with COVID-19 pneumonia in Babol North of Iran: a retrospective cohort study. Rom J Intern Med 2020;58:161-167.

2. Long B, Brady WJ, Koyfman A, Gottlieb M. Cardiovascular complications in COVID-19. Am J Emerg Med 2020;38:15041507.

3. Zheng YY, Ma YT, Zhang JY, Xie X. COVID-19 and the cardiovascular system. Nature Reviews Cardiology 2020;17:259-260.

4. Böhm M, Frey N, Giannitsis E, et al. Coronavirus Disease 2019 (COVID-19) and its implications for cardiovascular care: expert document from the German Cardiac Society and the World Heart Federation. Clin Res Cardiol 2020;109:1446-1459.

5. Kumar S, Haqqani H, Wynn G, et al. Position Statement on the Management of Cardiac Electrophysiology and Cardiac Implantable Electronic Devices in Australia during the COVID-19 Pandemic: A Living Document. Heart Lung Circ 2020;29:e57-e68.

6. Guzik TJ, Mohiddin SA, Dimarco A, et al. COVID-19 and the cardiovascular system: implications for risk assessment, diagnosis, and treatment options. Cardiovasc Res 2020;116:1666-1687. 
7. Wu C, Chen X, Cai Y, et al. Risk factors associated with acute respiratory distress syndrome and death in patients with coronavirus disease 2019 pneumonia in Wuhan, China. JAMA Intern Med 2020;180:934-943.

8. Juusela A, Nazir M, Gimovsky M. Two Cases of COVID-19 Related Cardiomyopathy in Pregnancy. Am J Obstet Gynecol MFM 2020;2:100113.

9. Bansal M. Cardiovascular disease and COVID-19. Diabetes Metab Syndr 2020;14:247-250.

10. Siripanthong B, Nazarian S, Muser D, et al. Recognizing COVID-19-related myocarditis: The possible pathophysiology and proposed guideline for diagnosis and management. Heart Rhythm 2020;17:1463-1471.

11. Deng Q, Hu B, Zhang $Y$, et al. Suspected myocardial injury in patients with COVID-19: Evidence from front-line clinical observation in Wuhan, China. Int J Cardiol 2020;311:116-121.

12. Khayyatzadeh SS. Nutrition and Infection with COVID-19. Shahid-Sadoughi-Univ-Med-Sci 2020;5:93-96.

13. Zhang $L$, Liu $Y$. Potential interventions for novel coronavirus in China: A systematic review. J Med Virol 2020;92:479-490.

14. Connors JM, Levy JH. COVID-19 and its implications for thrombosis and anticoagulation. Blood 2020:135:2033-2040.

15. Ponti G, Maccaferri M, Ruini C, et al. Biomarkers associated with COVID-19 disease progression. Crit Rev Clin Lab Sci 2020;57:389-399.

16. Tang A, Tong ZD, Wang $\mathrm{HL}$, et al. Early release - Detection of novel coronavirus By RT-PCR in stool specimen from asymptomatic child, China. Emerg Infect Dis 2020;26:1337-1339.

17. Pranata R, Huang I, Lukito AA, Raharjo SB. Elevated N-terminal pro-brain natriuretic peptide is associated with increased mortality in patients with COVID-19: systematic review and meta-analysis. Postgrad Med J 2020;96:387-391.

18. Gao L, Jiang D, Wen XS, et al. Prognostic value of NT-proBNP in patients with severe COVID-19. Respir Res 2020;21:83.

19. Mahajan K, Negi PC, Ganju N, Asotra S. Cardiac biomarker-based risk stratification algorithm in patients with severe COVID-19. Diabetes Metab Syndr 2020;14:929-931.

20. Gopinathannair R, Merchant FM, Lakkireddy DR, et al. COVID-19 and cardiac arrhythmias: a global perspective on arrhythmia characteristics and management strategies. J Interv Card Electrophysiol 2020;59:329-336.

21. Kochi AN, Tagliari AP, Forleo GB, et al. Cardiac and arrhythmic complications in patients with COVID-19. J Cardiovasc Electrophysiol 2020;31:1003-1008.

22. Rout A, Chan A. A Case of COVID-19 Complicated by Venous Thromboembolism Despite Being on Prophylactic Anticoagulation. J Med Cases 2020;11:189-191.

23. He J, Wu B, Chen Y, et al. Characteristic ECG manifestations in patients with COVID-19. Can J Cardiol 2020;36:966.e1-966.e4.

24. Wu Cl, Postema PG, Arbelo E, et al. SARS-CoV-2, COVID-19, and inherited arrhythmia syndromes. Heart Rhythm 2020;17:14561462.

25. Tsimploulis A, Rashba E, Rahman T, et al. Medication unmasked Brugada syndrome and cardiac arrest in a COVID-19 patient. HeartRhythm Case Rep 2020;6:554-557.

26. Singh R, Vijayan V. Chloroquine: A Potential Drug in the COVID-19 Scenario. Trans Indian Natl Acad Eng 2020;5:399410.

27. Liu J, Cao R, Xu M, et al. Hydroxychloroquine, a less toxic derivative of chloroquine, is effective in inhibiting SARS-CoV-2 infection in vitro. Cell Discov 2020;6:16.

28. Roy S, MainakMukhopadhyay. Ventricular Arrhythmia Risk Based on Ethnicity in COVID-19 Patients on Hydroxychloroquine and Azithromycin Combination: Viewpoint. SN Compr Clin Med 2020 Jun 27:1-6.

29. Fatima S, Bukhari S, Pacella J. The cardiovascular implications of COVID-19: A Comprehensive Review. Medical Research Archives 2020;8(5)

30. Rico-Mesa JS, White A, Anderson AS. Outcomes in Patients with COVID-19 Infection Taking ACEI/ARB. Curr Cardiol Rep 2020;22:31

31. Moore N, Carleton B, Blin P, et al. Does Ibuprofen Worsen COVID-19? Drug Saf 2020;43:611-614.

32. Kutti Sridharan G, Kotagiri R, Chandiramani VH, et al. COVID-19 and Avoiding Ibuprofen. How Good Is the Evidence? Am J Ther 2020;27:e400-e402.
33. Crotti L, Arbelo E. COVID-19 treatments, QT interval, and arrhythmic risk: The need for an international registry on arrhythmias. Heart Rhythm 2020;17:1423-1424.

34. Schulman S. Inhibition of Warfarin Activity by Ribavirin. Ann Pharmacother 2002;36:72-74.

35. Testa S, Prandoni P, Paoletti O, et al. Direct oral anticoagulant plasma levels' striking increase in severe COVID-19 respiratory syndrome patients treated with antiviral agents: The Cremona experience. J Thromb Haemost 2020;18:1320-1323.

36. Askin L, Tanriverdi O, Askin HS. O Efeito da Doença de Coronavírus 2019 nas Doenças Cardiovasculares. Arq Bras Cardiol 2020;114:817-822.

37. Veronese N, Demurtas J, Yang L, et al. Use of corticosteroids in coronavirus disease 2019 pneumonia: A systematic review of the literature. Front Med (Lausanne) 2020;7:170.

38. Schäcke H, Döcke WD, Asadullah K. Mechanisms involved in the side effects of glucocorticoids. Pharmacol Ther 2002;96:23-43.

39. The European Society for Cardiology. ESC Guidance for the Diagnosis and Management of CV Disease during the COVID-19 Pandemic. https://www.escardio.org/Education/ COVID-19-and-Cardiology/ESCCOVID-19-Guidance. (Last update: 10 June 2020)

40. Lakkireddy DR, Chung MK, Gopinathannair R, et al. Guidance for Cardiac Electrophysiology During the Coronavirus (COVID-19) Pandemic from the Heart Rhythm Society COVID-19 Task Force; Electrophysiology Section of the American College of Cardiology; and the Electrocardiography and Arrhythmias Committee of the Council on Clinical Cardiology, American Heart Association. Heart Rhythm 2020;17:e233-e241.

41. Davis G, Adlan A. COVID-19: Impact on cardiac procedural services. 2020.

42. Boukhris M, Hillani A, Moroni F, et al. Cardiovascular implications of the COVID-19 pandemic: a global perspective. Can J Cardiol 2020;36:1068-1080.

43. Mazzone P, Peretto G, Radinovic A, et al. The COVID-19 challenge to cardiac electrophysiologists: optimizing resources at a referral center. J Interv Card Electrophysiol 2020 May 18:1-7. doi: 10.1007/s10840-020-00761-7. Epub ahead of print. PMID: 32425656; PMCID: PMC7232930.

44. Matos RI, Chung KK. DoD COVID-19 Practice Management Guide: Clinical Management of COVID-19. Defense Health Agency Falls Church United States; 2020.

45. Mahase E, Kmietowicz Z. Covid-19: doctors are told not to perform CPR on patients in cardiac arrest. BMJ 2020 Mar 29;368:m1282.

46. Mahmud E, Dauerman HL, Welt FG, et al. Management of acute myocardial infarction during the COVID-19 pandemic. J Am Coll Cardiol 2020;76:1375-1384.

47. Zeng J, Huang J, Pan L. How to balance acute myocardial infarction and COVID-19: the protocols from Sichuan Provincial People's Hospital. Intensive Care Med 2020;46:1111-1113.

48. Luzi L, Radaelli MG. Influenza and obesity: its odd relationship and the lessons for COVID-19 pandemic. Acta Diabetol 2020;57:759-764.

49. Feng $\mathrm{S}$, Shen $\mathrm{C}$, Xia N, et al. Rational use of face masks in the COVID-19 pandemic. Lancet Respir Med 2020;8:434-436.

50. Güner R, Hasanoğlu I, Aktaş F. COVID-19: Prevention and control measures in community. Turk J Med Sci 2020;50:571577

51. McAleer M. Prevention is better than the cure: Risk management of COVID-19. J Risk Financial Manag 2020;13:46.

52. Singhvi $A$, Barghash $M$, Lala $A$, et al. Challenges in Heart Transplantation during COVID-19: A Single Center Experience. J Heart Lung Transplant 2020;39:894-903.

53. Holzhauser L, Lourenco L, Sarswat N, et al. Early experience of COVID-19 in 2 heart transplant recipients: Case reports and review of treatment options. Am J Transplant 2020;20:29162922.

54. Defilippis EM, Farr MA, Givertz MM. Challenges in Heart Transplantation in the Era of COVID-19. Circulation 2020;141:2048-2051.

55. Zhang $H$, Dai $H$, Xie X. Solid Organ Transplantation During the COVID-19 Pandemic. Front Immunol 2020;11:1392.

56. Chen $\mathrm{CY}, \mathrm{Chen} \mathrm{SF}$, Hollander SA, et al. Donor heart selection during the COVID-19 pandemic: a case study. J Heart Lung Transplant 2020;39:497-498. 